\title{
The Isolation of Rhodanese from Pseudomonas aeruginosa by Affinity Chromatography
}

\author{
BY RAYMOND W. RYAN AND RICHARD C. TILTON \\ University of Connecticut Health Center, Farmington, Connecticut 06032, U.S.A.
}

(Received 5 August 1977)

\section{INTRODUCTION}

Rhodanese (thiosulphate: cyanide sulphur-transferase; EC 2.8.I.I) was originally described by Lang (1933). The enzyme catalyses the formation of thiocyanate from cyanide and thiosulphate according to the reaction: $\mathrm{S}_{2} \mathrm{O}_{3}^{2-}+\mathrm{CN}^{-} \rightarrow \mathrm{SCN}^{-}+\mathrm{SO}_{3}^{2-}$. Rhodanese activity has been demonstrated in most mammalian tissues, with the greatest activity present in liver and kidney. The enzyme has been purified from liver (Horowitz \& DeToma, 1970) and kidney (Westley \& Green, 1959) as well as from several micro-organisms (Bowen, Butler \& Happold, I965; McChesney, I958; Smith \& Lascelles, 1966; Tabita, Silver \& Lundgren, 1969).

In this communication, the use of affinity chromatography in the partial purification of rhodanese from Pseudomonas aeruginosa is reported.

\section{METHODS}

Organism and growth conditions. The strain of Pseudomonas aeruginosa used in this study was a water isolate supplied by Dr C. W. Houston, Department of Bacteriology, University of Rhode Island. The organism was maintained on trypticase soy agar (BBL) slants at $4{ }^{\circ} \mathrm{C}$. A Fernbach flask containing I 1 trypticase soy broth (BBL) was inoculated with an overnight culture of $P$. aeruginosa to a density of $0.1 \mathrm{mg}$ dry wt ml ${ }^{-1}$, and shaken at 200 rev. $\mathrm{min}^{-1}$ in a New Brunswick Psychrotherm Incubator at $35^{\circ} \mathrm{C}$. After $6 \mathrm{~h}$ growth, the bacteria were harvested by centrifugation at $8^{\circ} \mathrm{C}$ in a Sorvall $\mathrm{RC}-2 \mathrm{~B}$ centrifuge at $10000 \mathrm{~g}$ for $15 \mathrm{~min}$.

Disruption of bacteria. The harvested bacteria were washed once with $6.7 \mathrm{mM}$-potassium phosphate buffer, $\mathrm{pH} 8.0$, and resuspended in $10.0 \mathrm{ml}$ of the same buffer containing I mM-sodium thiosulphate. The bacteria were sonicated at $5{ }^{\circ} \mathrm{C}$ for $30 \mathrm{~s}$ periods for a total of $3 \mathrm{~min}$ at maximum frequency, with a Bronwill Biosonik ultrasonicator (Bronwill Scientific, Rochester, New York, U.S.A.). The remaining whole bacteria and debris were removed by centrifuging at $10000 \mathrm{~g}$ for $30 \mathrm{~min}$. The suspension was then centrifuged at $30000 \mathrm{~g}$ for $45 \mathrm{~min}$ to remove the membrane fraction. The $30000 \mathrm{~g}$ supernatant was the starting material for the purification of rhodanese from $P$. aeruginosa.

Gel filtration. The initial step in the purification was fractionation on a Sephadex G-I00 column. The Sephadex G-Ioo was swollen in eluant buffer (6.7 mm-potassium phosphate buffer, $\mathrm{pH} 8 \cdot 0$ ) for $48 \mathrm{~h}$ and then degassed under vacuum. The crude cell-free extract was fractionated on a $2.5 \times 30 \mathrm{~cm}$ column at $5{ }^{\circ} \mathrm{C}$. The fraction volume was $5.0 \mathrm{ml}$. The three peak fractions containing rhodanese activity were selected for further purification using affinity chromatography.

Preparation of affinity column. The affinity gel was prepared by a procedure similar to that used by Mosbach et al. (1972). Settled Sepharose $4 \mathrm{~B}(60 \mathrm{ml})$ was activated by the cyanogen bromide method (Cuatrecasas, 1970). I,6-Diaminohexane ( $10 \mathrm{~g}$ ), dissolved in $100 \mathrm{ml} \mathrm{O} \cdot \mathrm{I} \mathrm{M}-\mathrm{NaHCO}_{3}$ buffer, was added to the activated Sepharose and the final $\mathrm{pH}$ was adjusted to 8.5 with $4 \mathrm{M}-\mathrm{NaOH}$. The suspension was stirred for $\mathrm{I} 5 \mathrm{~h}$ at room temperature. The gel was then filtered through a sintered glass funnel and washed extensively with, in turn, $0.1 \mathrm{M}-\mathrm{NaHCO}_{3}, 0 . \mathrm{I} \mathrm{M}-\mathrm{HCl}, 0.5 \mathrm{M}-\mathrm{NaCl}$, and distilled deionized water. It was then washed with a large volume of aqueous $80 \%(\mathrm{v} / \mathrm{v})$ pyridine. After filtration, the gel was transferred to a $250 \mathrm{ml}$ Erlenmeyer flask and $0.5 \mathrm{~g}$ lipoic acid, dissolved in $12 \mathrm{ml}$ pyridine was added, followed by $20 \mathrm{~g}$ dicyclohexylcarbodi-imide dissolved in $45 \mathrm{ml}$ pyridine. The flask was stoppered and gently agitated on a rotary shaker at room temperature. After shaking for 14 days, the gel was filtered and washed successively with $400 \mathrm{ml}$ of each of the 


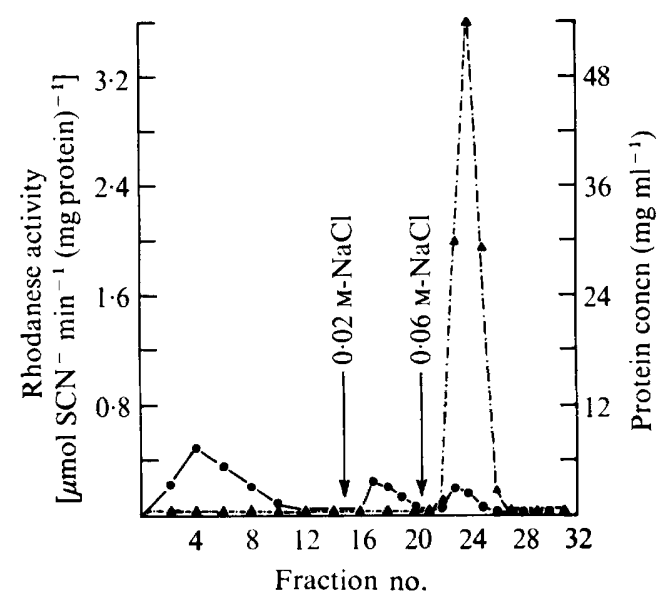

Fig. I. Elution of rhodanese from a Sepharose 4 B-lipoic acid affinity column. Eluant buffer: $6 \cdot 7 \mathrm{~mm}-$

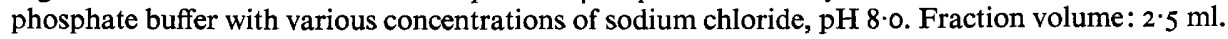
$\boldsymbol{\Delta}$, Rhodanese activity; $\boldsymbol{\theta}$, protein concentration.

following: distilled deionized water; ethanol; butanol; ethanol; distilled deionized water; 0.00I M-HCl for $20 \mathrm{~min} ; 0.1 \mathrm{M}-\mathrm{NaHCO}_{3} ; 0.5 \mathrm{M}-\mathrm{NaCl}$; and distilled deionized water.

Affinity chromatography. The gel was equilibrated with $6.7 \mathrm{~mm}$-phosphate/1 mM-sodium thiosulphate buffer, $\mathrm{pH} 8.4$, and the partially purified enzyme preparation was applied. The lipoic acid affinity column was then washed successively with $6 \cdot 7 \mathrm{~mm}$-potassium phosphate/I mM-sodium thiosulphate buffer, $\mathrm{pH} 8 \cdot 0$, the same buffer containing $0.02 \mathrm{M}-\mathrm{NaCl}$, and finally buffer containing $0.06 \mathrm{M}-\mathrm{NaCl}$. The affinity column was regenerated prior to reuse by washing with $0.5 \mathrm{M}-\mathrm{NaCl}$ and re-equilibrating with $6.7 \mathrm{~mm}$-phosphate/ $/ \mathrm{mm}$ sodium thiosulphate buffer, $\mathrm{pH} 8 \cdot 4$.

Enzyme assay. A modification of the procedure of Sorbo (1953) which measures the formation of thiocyanate from cyanide and thiosulphate, was used to measure rhodanese activity. The assay system consisted of $\mathrm{I} \cdot 0 \mathrm{ml} 0 . \mathrm{I} \mathrm{M}$-sodium thiosulphate, $\mathrm{I} \cdot 0 \mathrm{ml} \mathrm{O} \cdot \mathrm{I} \mathrm{M}-\mathrm{KCN}$ in $0.0 \mathrm{I} \mathrm{M}$-Tris/ $\mathrm{HCl}$ buffer, $\mathrm{pH} 9 \cdot 3$, and enzyme, in a final volume of $3.0 \mathrm{ml}$. The reaction mixture was incubated at $37^{\circ} \mathrm{C}$ for $\mathrm{I} 0 \mathrm{~min}$, and the reaction was stopped by the addition of $0.2 \mathrm{ml}$ of $37 \%(\mathrm{w} / \mathrm{w})$ formaldehyde. Two $\mathrm{ml}$ of $16 \%(\mathrm{w} / \mathrm{v})$ ferric nitrate in $\mathrm{I} \mathrm{M}-\mathrm{HNO}_{3}$ was added for colour development. The absorbance of the reaction mixture was measured in a Beckman DK-2A ratio recording spectrophotometer at $470 \mathrm{~nm}$, and compared with a standard curve constructed using known amounts of sodium thiocyanate. Protein was measured according to the method of Lowry et al. (195I).

\section{RESULTS AND DISCUSSION}

Hall \& Berk (1968) first reported the presence of rhodanese in Pseudomonas aeruginosa. In this organism, rhodanese is a constitutive enzyme and its level cannot be elevated by the incorporation of either thiosulphate or cyanide into the growth medium. This contrasts with the finding of Bowen et al. (I965), who demonstrated a several-fold increase in rhodanese activity by the incorporation of cyanide into the growth medium of Thiobacillus denitrificans.

Villarejo \& Westley (I963) reported that rhodanese isolated from beef liver catalysed the reduction of thiosulphate by reduced lipoic acid. It became apparent that if rhodanese from $P$. aeruginosa could interact with lipoic acid in the same way as the mammalian enzyme, it might be possible to further purify rhodanese by the use of a lipoic acid-Sepharose affinity column.

Mosbach and co-workers (1972) proposed the use of a hexacarbon 'spacer' molecule introduced between the Sepharose-gel matrix and the desired ligand. They reasoned that by displacing the ligand from the gel matrix, the steric availability for the desired enzyme(s) would be improved. An affinity gel was prepared by linking I,6-diaminohexane to Sepharose ${ }_{4} \mathrm{~B}$ using the cyanogen bromide method and subsequently coupling the lipoic acid, by means of a peptide bond, to the free amino group of the spacer molecule using the condensing 
agent dicyclohexylcarbodi-imide. When a partially purified rhodanese preparation was applied to this lipoic acid-Sepharose gel, containing a spacer molecule of approximately $0.7 \mathrm{~nm}$ in length, essentially all of the enzyme remained bound to the gel (Fig. I). Any 'non-specifically' bound protein was washed from the gel with buffer containing $0.02 \mathrm{M}$ sodium chloride. All of the rhodanese was eluted in a sharp peak by increasing the sodium chloride concentration in the buffer to $0.06 \mathrm{M}$.

The lipoic acid-Sepharose affinity gel might also be valuable in the isolation of rhodanese from other bacterial and mammalian sources. At present, the methods available for purifying rhodanese from mammalian sources in large quantities involve several ammonium sulphate fractionations, $\mathrm{pH}$ manipulation, and in some cases batch fractionation with DEAEcellulose (Sorbo, I953; Westley \& Green, 1959; Davidson \& Westley, 1965; Horowitz \& DeToma, 1970). These methods are quite time-consuming. A one-step purification system using lipoic acid bound to Sepharose should equal or surpass the level of purification achieved by either procedure.

\section{REFERENCES}

Bcwen, T. J., Butler, P. J. \& Happold, F. C. (I965). Some properties of the rhodanese system of Thiobacillus denitrificans. Biochemical Journal 97, 65I-657.

Cuatrecasas, P. (1970). Protein purification by affinity chromatography. Journal of Biological Chemistry 245, 3059-3065.

Davidson, B. \& Westley, J. (I965). Tryptophan in the active site of rhodanese. Journal of Biological Chemistry 240, 4463-4469.

HALL, M. R. \& BERK, R. S. (I968). Microbial growth on mercaptosuccinic acid. Canadian Journal of Microbiology 14, 51 5-523.

Horowitz, P. \& DeToma, F. (1970). Improved preparation of bovine liver rhodanese. Journal of Biological Chemistry 245, 984-985.

LANG, K. (1933). Die Rhodanbildung im Tierkörper. Biochemische Zeitschrift 263, 262-267.

Lowry, O. H., Rosebrough, N. J., Farr, A. L. \& RANDALL, R. J. (I95I). Protein measurement with the Folin-phenol reagent. Journal of Biological Chemistry 193, 265-275.

MCCheSney, C. A. (1958). Occurrence of rhodanese in a species of Thiobacillus. Nature, London $\mathbf{1 8 1}$, 347-348.

Mosbach, K., Guilford, H., Ohlsson, R. \& ScotT, M. (1972). General ligands in affinity chromatography. Biochemical Journal 127, 625-631.

Smith, A. J. \& Lascelles, J. (1966). Thiosulphate metabolism and rhodanese in Chromatium sp. strain D. Journal of General Microbiology 42, $357-370$.

Sorbo, B. H. (1953). Crystalline rhodanese. I. Purification and physicochemical examination. Acta chemica scandinavica 7, I1 29-1 I36.

TABita, F. R., Silver, M. S. \& Lundgren, D. G. (1969). Partial purification and properties of rhodanese from Ferrobacillus ferro-oxidans. Bacteriological Proceedings, 64.

Villarejo, M. \& Westley, J. (1963). Rhodanesecatalyzed reduction of thiosulfate by reduced lipoic acid. Journal of Biological Chemistry 238, I I 85-I I 87.

Westley, J. \& Green, J. R. (I959). Crystalline beef kidney rhodanese. Journal of Biological Chemistry 234, 2325-2326. 